Отримано: 27 квітня 2018 р.

Прорецензовано: 29 травня 2018 р.

Прийнято до друку: 1 червня 2018 р.

e-mail: storchak.maria@gmail.com

DOI: $10.25264 / 2519-2558-2018-2(70)-31-34$
Storchak M. The ing-form specifics in complements in contemporary English. Наукові записки Національного університету «Острозька академія»: серія «Філологія». Острог : Вид-во НаУОА, 2018. Вип. 2(70), червень. С. 31-34.

\author{
Maria Storchak, \\ Teacher of the Foreign Languages Department, \\ Kharkov National Automobile and Highway University
}

\title{
THE ING-FORM SPECIFICS IN COMPLEMENTS IN CONTEMPORARY ENGLISH
}

The results of this research shed new light on the synchronic processes of the construction of gerundive clauses. Methodology of this research is based on the contextual analysis of the utterances which contain gerunds as complements. There are three essential parameters for explaining complement usage with the ing-form: the meaning of the main verb, the meaning of the ing-complement form and the sense of the utterance in discourse. The criteria that determine the choice of either the to-infinitive or the gerund as a complement are the meanings of a sentence and a main verb, the stance of the speaker, syntactic and semantic factors. The ing-complement form occurs in same-time, backward-looking, forward-looking constructions and in the contemplation construction type. Verbs can be followed by exclusively the gerund or the infinitive, by both the gerund and the infinitive with no change in meaning or with a change in meaning. The opposition between the infinitive and the gerund is sometimes seen as the difference between a particular case and a universal sense. The relation in time between the two events is a function of the lexical content of the main verb.

Key words: verb, complement, gerundive clause, ing-form, semantic factor, syntactic factor, sense.

\author{
Сторчак Марія Олегівна, \\ викладач кафедри іноземних мов, \\ Харківський наиіональний автомобільно-дорожній університет
}

\section{СПЕЦИФІКА-ING ФОРМИ ДІЕСЛОВА В ФУНКЦІЇ ДОДАТКА У СУЧАСНІЙ АНГЛІЙСЬКІЙ МОВІ}

Істотними параметрами, щчо обумовлюють використання інгової форми дієслова в функції додатка у герундіальному реченні, є значення смислового дієслова основного речення, значення інгової форми дієслова та смисл висловлювання. Критеріями, щзо обумовлюють вибір інгової форми або інфінітиву, є смисл висловлювання, значення смислового дієслова, установка мовия, синтаксичні та семантичні фактори.

Ключові слова: дієслово, додаток, герундіальне речення, інгова форма дієслова, семантичний фактор, синтаксичний фактор, смисл.

Сторчак Мария Олеговна,

преподаватель кафедры иностранных языков,

Харьковский нацииональный автомобильно-дорожный университет

\section{СПЕЦИФИКА -ING ФОРМЫ ГЛАГОЛА В ФУНКЦИИ ДОПОЛНЕНИЯ В СОВРЕМЕННОМ АНГЛИЙСКОМ ЯЗЫКЕ}

Существенными параметрами, обусловливаюшими использование инговой форми глагола в дополнении герундиального предложения, являются значения смыслового глагола основного предложения и инговой формы, а также смысл высказывания. Критериями выбора инговой формы или инфинитива являются смысл высказывания, значение смыслового глагола, установка говорящеге, синтаксические и семантические факторы.

Ключевые слова: глагол, дополнение, герундиальное предложение, инговая форма, семантический фактор, синтаксический фактор, смысл.

This study focuses on the clausal complements containing the form of the verb ending in -ing. The ing-form denotes traditional grammatical terms such as the gerund and the present participle. In some descriptions of grammar the complement refers to any word or phrase which is governed by a verb and usually comes after the verb in a sentence [10, p. 308].

The main problem is lack of reliable essential parameters for explaining the complement usage of the ing-form and the infinitive. The aim of this paper is to describe the specifics of the ing-form in complements in the utterances of contemporary English. The object of this study is the ing-form; the subject is the specifics of the ing-form in complements. This research is of topical interest as ing-forms are frequently used in English discourse and are important to describe and recognize speech events. Linguistic regularities in the use of ing-forms in complements are essential for teaching and learning English.

Methodology of this research is based on the contextual analysis of the utterances which contain gerunds as complements. A novelty value is the enhancement of both the scientific notion of the ing-form and the methodological principles of teaching by the essential parameters of the ing-complement form usage. The verbal phrases in this study are classified along the function parameter of the ing-complement form and the semantics of the main predicate verb in the complement clause. The tokens are based on data in various dictionaries and literary sources. We examine naturally occurring usage in context.

The English gerund system is a deverbal structure that can take two different forms: a nominal gerund (the learning of a language), having the internal syntax of a noun phrase, and a verbal gerund (learning a language) that is developed out of the nominal gerund [5, p. 37]. The nominal gerund existed long before the verbal gerund [11]. The gerund gradually acquired verbal properties, such as the ability: a) to govern an object or a predicative complement (She always hated his teasing the girls/ my being an atheist); b) to be modified by adverbs or adverbials which only co-occur with verbs (by gently stroking the cat); c) to show tense and voice dis- 
tinctions (the harm in having eaten the plastic wrapper; dreams of being chased); $\mathrm{d}$ ) to be negated by means of the negating particle not (my father's not caring); e) to take a subject in a case other than the genitive (I don't like him being around Ann) [5, p. 37-38].

To differentiate the ing-form from the infinitive in a clausal complement, some researchers focus on the traditional opposition between generality (with the gerund) and particularity (with the infinitive) though usage shows that the gerund and the infinitive can both express these two types of reference [3, p. 361]. Scholar A. Wierzbicka considers two kinds of ing-complements: temporal and non-temporal, the former implies simultaneity for actions, processes and states whereas the latter refers to facts or possibilities [12, p. 69, 164.]. According to P. Duffley, the distinction between the gerund and the infinitive can be defined neither in terms of an opposition between generality and specificity nor in terms of a contrast between simultaneity and futurity. The evidence shows that the ing-form is simply the direct object of the main verb in some cases [3, p. 364]. Gerunds as direct object of another verb imply that events in gerund complements can occur at the same time with that of the main predicate as in (a) or at the time corresponding to the main verb as in (b): (a) Sue was enjoying dancing with him; (b) Sue remembers sending Lisa a present. Researchers M. Celce-Murcia and D. Larsen-Freeman note that actions in the gerund complement can be encoded ongoing in the present or completed in the past [1, p. 648]. The infinitive in the following token evokes an action as completely carried out from its beginning to its end: I saw your cat cross the street. In the next token, the ing-form shows that the action is not fulfilled completely: I saw your cat crossing the street. It is believed that gerunds generally imply fulfillment and reality. Some researchers argue that gerunds signal an actual event: Sue enjoys talking with Lisa; Sue enjoyed playing tennis with Lisa. Gerunds talking and playing denote that Sue and Lisa actually played tennis and Sue succeeds in talking with Lisa. Only fulfilled actions can accompany enjoy.

In English there are two main types of constructions containing active-voice finite verbs (the main clause predicate) and complements (the complement clause predicate): 1) same-subject constructions, in which the subject of the complement clause predicate is identical to the subject of the main verb, and 2) different-subject constructions, in which the subject of the complement predicate is profiled as distinct from the subject of the main verb. The ing-complement form occurs in same-time, backward-looking, forwardlooking constructions and the contemplation construction type, which is always a mental process [4, p. 107-109]. Same-time constructions: 1) I adored her being there in a place I equate with hell. 2) The two men continued walking, trying to fathom the mystery of the fogbound train. Backward-looking constructions: 1) The warden at the time remembers seeing someone like Eila, but they could find no record of her name. 2) Richard Baylis, defending, said his client admitted smoking heroin in the past but had told him he would not be going near it again. Forward-looking constructions: 1) Then we envisage starting a housegroup on the estate. 2) The Data Protection Act forbids us releasing names and addresses of members without their permission. Contemplation construction: She had never imagined wearing clothes like this.

The ing-form in complement constructions has two properties: durative and imperfective [4, p. 109, 128]. Scholar R. Dixon writes that "an -ing complement refers to an activity or state as extended in time, perhaps noting the way in which it unfolds" [2, p. 218]. Scholar R. Langacker maintains that adding -ing to a perfective stem creates an imperfective relation that profiles a process as unfolding [7, p. 91]. For example: 1) I recall her pacing the sitting-room while I am doing my homework, pausing every so often to stand at one of the windows and look down into the busy street below; 2) She could hear Penry moving about upstairs as he made up the other bed.

According to E. M. Gordon and I. P. Krylova, the ing-form is used in the functions as follows:

1) the ing-form as subject: Passing a law about equal rights doesn't necessarily mean that women get them. There's no denying that;

2) the ing-form as predicative: The important part is helping people. To read his novels was like swimming in a lake;

3) the ing-form as predicate: What about going to London? How about seeing what they are doing now? But letting him do it!;

4) the ing-form as part of a compound verbal predicate: They all sat around feeling very proud. In this function the ing-form is lexically dependent and is used after verbs denoting motion or position: to come, to go, to go out/about/ round/around, to lie, to sit, to sit around/ round, to stand, to stand around/ round, to disappear;

5) the ing-form as a second action accompanying the action of the predicate verb. The subject of the ing-form is the same as the subject of the sentence: They ran up the stairs brimming with excitement. Having duly arrived in Scotland, he took a train the next day. Miss Smith was in her office typing;

6) the ing-form as object: English grammar is very difficult and few writers have avoided making mistakes in it. The ing-form is used as object to a direct or prepositional verb. It is lexically dependent. For example: Let's get down to signing the papers;

7) the ing-form as subjective predicative is lexically dependent after a number of verbs in the Passive: catch, find, hear, leave, notice, report, see, set, show, and watch. For example: The baby was found sitting on the floor. Here also belong a few verbs after which the ing-form is introduced by as: At school Janet and I were considered as going together;

8) the ing-form as objective predicative is lexically dependent after a number of transitive verbs in the Active followed by an object which is expressed by a noun or a pronoun. The following are the most frequently used verbs taking a direct object: call, catch, discover, feel, find, hear, get, imagine, keep, leave, like, dislike, notice, picture, see, send, set, stop, watch, want. For example: I felt him looking at me;

9) the ing-form as adverbial modifier to a verb. In this case it is preceded by a conjunction or a preposition which lend it adverbial meanings, such as time, concession, condition, attending circumstances, manner, cause, and some others. The ing-form may be preceded by the conjunctions while, when, once, if, as though, as if, though, than, as well as and correlative conjunctions as...as, not so... as. For example: He continued to speak while walking down the path. He listened as though brooding. Nothing is so dangerous as being too modern;

10) the ing-form as a part of an absolute construction where the ing-form may have a subject of its own: His study was a nice room with books lining the walls. She looked at him, her face radiantly smiling. Absolute constructions denote a second action and acquire adverbial meanings: A room lit up on the third storey, someone working late;

11) the ing-form as attribute. The ing-form may immediately precede its head-noun: a barking dog, the setting sun, trembling hands, the burning questions, a creaking laugh. It is typical of the ing-form in this function to become adjectivised: the idea of action is absent; 
12) the ing-form as parenthesis tends to become a set phrase: Secrets, generally speaking, are not very well kept nowadays. It goes without saying that healthy men are happier than sick men [6, p. 169-190].

The gerund is used in the following cases:

1) as the subject, object and complement of a sentence: Playing golf helps me relax; I find watching it on television rather boring;

2) after prepositions: We thought about going to France this year;

3) after the following expressions: have difficulty/ problems, there's no/ little point, it's no good/ use, it's (not) worth: It's no use asking him - he won't know the answer;

4) after the following verbs: admit, adore, advise, anticipate, appreciate, avoid, can't help, can't stand, consider, delay, deny, detest, dislike, dread, enjoy, feel like, give up, imagine, involve, keep, (don't) mind, miss, postpone, practice, prevent, propose, put off, recommend, resent, resist, risk, suggest: I resent having to do all the housework myself. We appreciate your coming to tell us so quickly;

5) after the following verbs + the preposition to: adapt/adjust to, admit to, confess to, get round to, get used to, look forward to, object to: She confessed to being surprised by his success [8, p. 218].

The following verbs can be followed by the gerund or the to-infinitive with no change in meaning: begin, can't bear, continue, hate, intend, like, love, prefer and start [8, p. 218]. For example, She suddenly started singing/ to sing. The infinitive is common for specific situations and the gerund is used to describe an event in general. Compare: I hate to say this, but your breath smells; I hate getting up early in the morning. The verbs like, love, hate, prefer have little, if any, difference in meaning when used with the to-infinitive or the ing-form $[9$, p. 210].

The verbs that can be used with both the to-infinitive and the ing-form with a change in meaning are as follows: forget, remember, try, go on, mean, need, and stop [9, p. 210]. The gerund that is preceded by the verbs forget, regret, remember, stop is used when the act that is expressed by the gerund comes first: I distinctly remember posting the letter yesterday. The to-infinitive follows remember, forget, regret, stop when the act expressed by the infinitive comes second: I must remember to post this letter later [8, p. 218]. If the leading verbs remember, forget, regret, stop express the first action in time, the next action is represented by the to-infinitive.

The model try + to do is used when it means 'attempt to do'; the model try + doing is used when it means 'experiment with doing'. For example, I am trying to sleep and try using earplugs. The model mean + to do is used when it means 'intend to do'; the model try + doing is used when it means 'involve doing' [8, p. 218]. Compare: I have been meaning to write you for ages; Changing jobs also means changing house. So the models verb + to do and verb + doing encapsulate the meaning.

In the case of gerund complements, the verbs forget, remember, try usually mean that the subject of the main clause completed or fulfilled an action, whereas in the case of infinitive complements, they usually denote future unfulfilled action of the subject of the main clause [1, p. 648-649]. For example:

1. He forgot to call his parents. (He didn't call his parents because of his forgetfulness.) He forgot calling his parent. (He didn't remember if he had called his parents.)

2. We must remember to feed the cat. (Remember what you have to do.) I remember coming here when I was young. (To recall a previous action.)

3. I should try to eat more fruit. (You should make an effort/ an attempt to eat more fruit.) You should try eating more fruit. (You should see if eating more fruit will help you. Do an experiment in order to see what will happen) [10].

The verbs like, love, enjoy, relish, fancy, appreciate, want, wish, desire, long, yearn, hanker, pine, hunger and thirst are used with the infinitive and the gerund as complements. The verbs like and love admit both forms of complementation, whereas the other verbs in this semantic group are construed either with the gerund (enjoy, relish, fancy, appreciate) or with the infinitive (want, wish, desire, long, yearn, hanker, pine, hunger, thirst). Verbs such as like and love are capable of evoking an enjoyment and a desire, inclination. Enjoyment implies coincidence in time between the liking and the event liked. The verbs like and love have the far greater frequency of the to-infinitive as compared to the gerund in British and American English. Researcher P. Duffley uses two types of selection criteria: structural rules, such as the restriction of the verb dislike to construal with only ing-complements, and semantic selection rules. When the verb like is used to express a polite way to say what you want or to ask what somebody wants, we can use would or should: I'd like to think it over; We'd like you to come and visit us [10]. The syntactic and semantic criteria are necessary to account for the choice of complement with the verbs of liking.

Thus, these findings shed new light on the synchronic processes of the construction of gerundive utterances. The ing-complement form occurs in same-time, backward-looking and forward-looking constructions as well as in the contemplation construction type. There are three essential parameters for explaining complement usage with the ing-form: the meaning of the main verb, the meaning of the complement form and the sense of the sentence. The criteria that determine the choice of either the to-infinitive or the gerund as a complement are the meanings of sentence and the main verb, the stance of the speaker, syntactic and semantic factors. The opposition between the infinitive and the gerund is seen as the difference between a particular case and a universal sense. Verbs can be followed by the gerund and the infinitive with no change in meaning, with a change in meaning, exclusively with the gerund or the infinitive. The relation in time between the two events is a function of the lexical content of the main verb.

Further research will be focused upon the aspects of the verbalization and nominalization of the ing-form in a diachronic approach.

\section{References:}

1. Celce-Murcia M., Larsen-Freeman D. The grammar book: an ESL/ EFL teacher's course. $2^{\text {nd }}$ ed. Boston: Heinle \& Heinle, 1999. 849 p. URL: https://flaviamcunha.files.wordpress.com.

2. Dixon R. M. W. A new approach to English grammar, on semantic principles. Oxford : Clarendon Press, 1992. 398 p. URL: https:// books.google.com.ua.

3. Duffley P. J. Verbs of Liking with the Infinitive and the Gerund. Journal of English Linguistics. 2003.31 (4). P. 324-352.

4. Egan Thomas. Non-finite complementation: A usage-based study of infinitive and -ing clauses in English. Language and Computers: Studies in Practical Linguistics. Amsterdam-New York : Rodopi, 2008. No 65. 432 p.

5. Fonteyn L., De Smet H., Heyvaet L. What It Means to Verbalize: The Changing Discourse Functions of the English Gerund. Journal of English Linguistics. 2015. Vol. 31. Issue 1. P.36-60. URL: http://citeseerx.ist.psu.edu. 
6. Gordon E. M., Krylova I. P. A Grammar of Present-Day English (Parts of Speech). Moscow : Vyssaja skola, 1980. 2 ed. 335 p.

7. Langacker R. W. Foundations of Cognitive Grammar: Descriptive applications. Berlin : Mouton de Gruyter, 1991. 628 p.

8. Norris Roy, French Amanda. Ready for Advanced : coursebook with key. 3rd ed. Macmillan exams, 2015. 280 p.

9. Norris Roy. Ready for First : coursebook with key / Roy Norris. 3rd ed. Macmillan exams, 2015. 278 p.

10. Oxford Advanced Learner's Dictionary / managing eds Margaret Deuter, Jennifer Bradbery, Joanna Turnbull. Oxford University Press, 2006. 9 ed. 1820 p.

11. Tabor Whitney, Elisabeth Closs Traugott. Structural scope expansion and grammaticalization. The limits of grammaticalization. Anna Giacalone Ramat, Paul J. Hopper (eds.). Amsterdam: John Benjamins, 1998. 229-272 p.

12. Wierzbicka Anna. The Semantics of Grammar. John Benjamins Publishing company Amsterdam/ Philadelphia, 1988. 620 p. 